\title{
US scientists call for fairer animal funding
}

[WASHINGTON] Scientific societies in the United States are challenging a government policy that they claim is harming biomedical research by selectively punishing investigators who work with animal models.

Last week, 75 societies, led by the American Association of Immunologists and the American Physiological Society, wrote to Harold Varmus, director of the National Institutes of Health (NIH), and William Raub, a top science policy adviser in the Department of Health and Human Services, to protest at guidelines on repaying overhead costs of animal research facilities (ARFs).

The letter attacks the current policy, under which these may not be billed to an institution's general overheads. Many institutes have responded by billing investigators directly. The societies call this situation "a hindrance to progress" on diseases that require animal models, because it makes proposals using animals seem more expensive.

The problem arises from the fact that the government, led by the White House Office of Management and Budget (OMB), has in recent years set about enforcing - albeit very unevenly - a policy that has officially been on the books since 1979 .

Institutions including Harvard University and the University of Chicago have been forced to bill investigators directly for overhead costs at their ARFs, whereas some, such as Columbia University, remain unscathed. Others, such as Yale University, have had to stop charging overhead costs to the indirect cost pool, but have cushioned their scientists by covering the charges from other university funds.

Scientists believe that this has created an uneven playing field for proposals going before NIH study sections, where reviewers may be tempted to select a grant applicant who can complete a project at a lower cost.

The government's accountants maintain that ARFs are "specialized service facilities", which, like wind tunnels and research reactors, cannot charge overheads to the indirect cost pool. The system, the government believes, not only makes scientists using the facilities more cost-conscious but also prevents the broader community subsidizing expensive, highly specialized facilities.

But scientists say that classifying ARFs as "specialized" no longer makes sense, as advances in animal research in the past two decades - in particular the explosion in work on transgenic and knockout mice have changed ARFs from holding stations for animals into genuine research space, just like any investigator's laboratory.

"The research community has really been almost speaking with one voice on this," says Judith Vaitukaitis, the director of the National Center for Research Resources (NCRR) at
NIH. "What they are saying is that research with animals is like research with test tubes, or any other part of biomedical research, and should be treated as such."

Encouraged by a recent report from the National Research Council (NRC) endorsing its views, the scientific community is taking on the government. "Scientists will become reluctant to pursue important lines of research involving animal models out of concern that their research has less chance to be funded," says its letter. It urges the government to reverse course and adopt the recommendations of the NRC report, which was requested by NCRR and released in June.

The report calls the current policy "misguided" and urges the government to allow institutions to meet ARF overhead costs from the indirect cost pool. The authors see "no reason to single out animal research". They estimate that implementing the policy doubles the average animal housing rates charged to scientists.

Varmus, Raub and cost-accounting officials from the Department of Health and Human Services were due to be briefed on the report by its authors on Monday (14 September). Raub said before the briefing that the report would receive a "very serious look" from the department's officials. But any change in policy would have to win the approval of OMB.

MeredithWadman

\section{Spain lets Latin America 'repay' debts by protecting environment}

[BARCELONA] Spain has agreed to a US $\$ 70$ million 'debt for nature' swap to aid biodiversity conservation in Latin America, in what government officials call "the most ambitious project in the history of Spanish international cooperation".

Latin American countries that owe substantial sums to Spain will be allowed to use the money to protect and improve the local environment. The project is called Araucaria, after an Andean conifer, and the money will support the development of communities living near some of Latin America's most important ecosystems.

All improvements carried out with funds owed to Spain will be performed with Spanish technology and equipment.

The five-year project will be officially launched next month. Prince Felipe gave it his support during a visit last month to the Galápagos archipelago, where Spanish Foreign Office technicians and scientists are drawing up schemes for inclusion.

This is the first time an economic mechanism has been set up in Spain to cancel a substantial part of Latin American countries' debt in return for a commitment to preserve the natural environment.

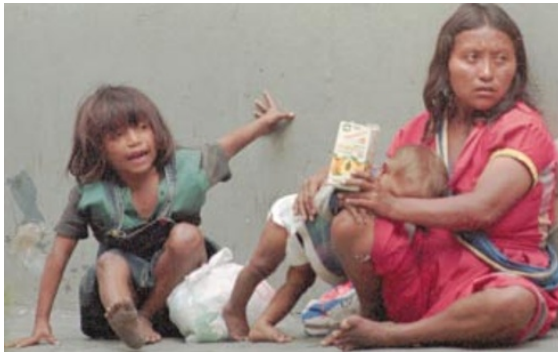

City beggars in Venezuela: the new scheme could help people earn a living in their home villages.

One of the main purposes of Araucaria is to protect biodiversity in areas especially sensitive to human action. Researchers are trying to work out how to promote the development of local communities without putting biodiversity in jeopardy.

"It is a pioneer initiative that responds to a historical plea of Latin American debtor countries," says Jesús García, head of the Institute for Latin American Cooperation. "Spain is fulfilling a commitment it made in 1992 during the Earth Summit conference in Rio de Janeiro."

A typical Araucaria project is the construction of a road joining Iquitos, the capital of Peruvian Amazonia, and Nauta village, which stands at the entrance to the Pacaya-Samiria nature reserve. This will open up non-destructive methods of production by increasing tenant farmers' access to previously inaccessible areas.

José María Aznar, Spain's prime minister, will visit Iquitos this month to inspect Araucaria's activities in the area. Other projects are under way in the Colca valley in Peru, and in Savegre valley, Costa Rica.

"Araucaria will lead to concrete links between economic issues and those concerning the conservation of the natural environment," says Alvaro Rengifo, head of the Department of Foreign Investments. "It will allow the experience of projects already running in Costa Rica and Peru to be reproduced in other countries."

Many experts see such agreements as a strategy that can help preserve one of the Earth's most important regions of biodiversity. The task will not be simple it will require complex legal steps, as well as the approval of the parliaments involved.

García says the main advantage of Araucaria "is its coordinated and selective nature”.

Xavier Bosch 